\title{
Antileishmanial activity of 3-(3,4,5-trimethoxyphenyl) propanoic acid purified from Amazonian Piper tuberculatum Jacq., Piperaceae, fruits
}

\author{
Maria Goretty P. R. Ferreira, ${ }^{\#, I}$ Anderson M. Kayano, ${ }^{2}$ Izaltina Silva-Jardim, ${ }^{1}$ Tatiany O. da \\ Silva, ${ }^{1}$ Juliana P. Zuliani, ${ }^{1,2}$ Valdir A. Facundo, ${ }^{3}$ Leonardo de A. Calderon, ${ }^{1,2}$ \\ Alexandre de Almeida-e-Silva, ${ }^{1,4}$ Pietro Ciancaglini, ${ }^{5}$ Rodrigo G. Stábeli ${ }^{*}, 1,2$
}

\begin{abstract}
${ }^{1}$ Instituto de Pesquisas em Patologias Tropicais de Rondônia, Fundação Oswaldo Cruz, Fiocruz Noroeste, Rua da Beira 7671, BR364, km 3.5, 76812-245 Porto Velho-RO, Brazil,

${ }^{2}$ Centro de Estudos de Biomoléculas Aplicadas a Medicina Prof. Dr. José Roberto Giglio, Núcleo de Saúde,

Universidade Federal de Rondônia, BR 364, km 9.5, 76800-000 Porto Velho-RO, Brazil,

${ }^{3}$ Laboratório de Química Orgânica, Núcleo de Ciência e Tecnologia, Universidade Federal de Rondônia, BR 364, km 9.5, 76800-000 Porto Velho-RO, Brazil,

${ }^{4}$ Laboratório de Bioecologia de Insetos, Núcleo de Ciência e Tecnologia, Universidade Federal de Rondônia, BR 364, km 9.5, 76800-000 Porto Velho-RO, Brazil,

${ }^{5}$ Departamento de Química, Faculdade de Filosofia Ciências e Letras de Ribeirão Preto, Universidade de São Paulo, 14040-901 São Paulo-SP, Brazil.
\end{abstract}

\begin{abstract}
RESUMO: "Atividade antileishmania do 3,4,5-trimetoxi-dihidrocinâmico purificado das frutas de Piper tuberculatum Jacq., Piperaceae, amazônica”. A atividade leishmanicida do ácido 3,4,5-trimetoxi-dihidrocinâmico (TMPP) isolado do extrato hidroalcoólico de frutos de Piper turbeculatum Jacq. amazônica foi testado em ensaios in vitro utilizando formas promastigotas de Leishmania amazonensis. OTMPP foi utilizado em culturas de L. amazonensis nas concentrações de 1600 a $6,25 \mu \mathrm{g} / \mathrm{mL}$. A viabilidade celular das formas promastigotas foi observada em 24, 48, 72 e $96 \mathrm{~h}$ para cálculo da CI50. O TMPP apresentou efeito leishmanicida dose dependente para as formas promastigotas de L. amazonensis apresentando CI50 de 145 $\mu \mathrm{g} / \mathrm{mL}$.
\end{abstract}

Unitermos: Piper tuberculatum Jacq., Piperaceae, ácido 3,4,5-trimetoxi-dihidrocinâmico, Leishmania amazonensis, atividade leishmanicida.

\begin{abstract}
Leishmanicidal activity of the 3-(3,4,5-trimethoxyphenyl) propanoic acid (TMPP) isolated from EtOH extracts of the Amazonian Piper turbeculatum Jacq. fruits was evaluated in vitro using Leishmania amazonensis promastigotes. The TMPP was assayed at concentrations of 1600 to $6.25 \mu \mathrm{g} / \mathrm{mL}$ for $24,48,72$ and $96 \mathrm{~h}$. Promastigotes viability was analyzed and the IC50 of TMPP was $145 \mu \mathrm{g} / \mathrm{mL}$.
\end{abstract}

Keywords: Piper tuberculatum, Piperaceae, 3-(3,4,5-trimethoxyphenyl) propanoic acid, Leishmania amazonensis, leishmanicidal activity.

\section{INTRODUCTION}

Leishmaniasis is a broad group of parasitic diseases with a wide spectrum of morbidity. It is currently estimated that 350 million people are at risk, and that more than two million new cases occur annually (Reithinger et al., 2007). Leishmaniasis treatments present many problems such as potentially toxic drugs with parenteral administration, several collateral effects, resistance to medication and the need for long term treatment (Santos et al., 2008).

The above mentioned, in addition to the emergence of drug resistance and the absence of oral preparations, encourages innovation in the development of new drugs against leishmaniases parasites. Many researches have been done in order to find new compounds from the biodiversity with potential leishmanicidal activity (Calderon et al., 2009; Rocha et al., 2009; Flores et al., 2008; Paula-Júnior et al., 2006).

Thus, Piper is a genus that is both economically 
and ecologically significant and includes a fascinating array of vegetal species for the study of natural products in organic chemistry, pharmaceutics products, and ethnobotany. The Piper genus includes more than a hundred species and is one of the largest genera of basal angiosperms distributed pantropically as shrubs, herbs, and lianas. The greatest diversity of Piper species occurs in the tropics of the Americas (about 700 spp.), followed by Southern Asia (300 spp. approximately) (Jaramillo \& Manos, 2001).

Extracts from Piper are employed by people throughout the tropics for many purposes, such as antimicrobial, antifungal , antipyretic, aromatic, diuretic, emetic, fish bait, food, hallucinogen, ornamental, perfume, spices, styptics, sudorific, as well as many other medicinal recipes (Wadt et al., 2004). These uses demonstrate some of the array of biological properties of the chemicals present in these species, which have potential pharmacological applications (Kato \& Furlan, 2007). Most of the compounds isolated from the Piper species are essential oils, lignans, phenylpropanoids, and sesquiterpenes (Facundo et al., 2008). Some of these molecules have economic value, such as sassafras oil or Safrole, an important raw material for the chemical industry (Rocha \& Ming, 1999).

The Piper tuberculatum Jacq., Piperaceae, is popularly known in the Northeast of Brazil as "pimentalonga" or "pimenta-d'arda" (Facundo et al., 2008). Local communities have traditionally used this species as an anesthetic sedative for toothache, antidote for snake bite, stimulants, and stomach problems (Chaves et al., 2003). Recent studies showed that different extracts and isolated molecules from $P$. tuberculatum present antifungal (Lago et al., 2004), antitumor (Bezerra et al., 2006), antiplatelet aggregation (Fontenele et al., 2009), insecticide (Pohlit et al., 2004) and hypotensive properties (Duarte et al., 2004).

In this short communication we report the preliminary in vitro antileishmanial activity of $3-(3,4,5-$ trimethoxyphenyl) propanoic acid (TMPP) purified from Piper tuberculatum Jacq fruits.

\section{MATERIAL AND METHODS}

Fresh fruits of Piper tuberculatum Jacq., Piperaceae, were collected around the city of Porto VelhoRO, Brazil (Southwestern Amazon). A voucher specimen (211724) was deposited in the herbarium of the Instituto Nacional de Pesquisas da Amazônia, Manaus-AM, Brazil. The fruits $(1.5 \mathrm{~kg})$ were dried, powdered and extracted with $95 \% \mathrm{EtOH}(3 \mathrm{x} 1.0 \mathrm{~L})$. The extract was concentrated, delipidated by $n$-hexane, and partitioned with EtOAc. The EtOAc layer was concentrated and the fractions were chromatographed on silica gel column (200-300 mesh, $80 \mathrm{~g}$ ) and eluted with $n$-hexane and subsequently by $n$-hexane/EtOAc mixtures $(19: 1,9: 1$ and $2: 1, \mathrm{v} / \mathrm{v}$, increasing polarity) to give more eighteen fractions. Fraction $12(124.2 \mathrm{mg})$ was re-chromatographed in silica gel $(20 \mathrm{~g})$ eluted with $n$-hexane/EtOAc (4:6) and yielded the purified compound TMPP $(56.5 \mathrm{mg})$. The chemical identity of the 3-(3,4,5-trimethoxyphenyl) propanoic acid (1) was performed on the basis of their ESI-MS,1D and 2D NMR data according to Facundo et al. (2008). TMPP (10 mg) was diluted in $2000 \mu \mathrm{L}$ of $20 \%$ dimethyl sulfoxide (DMSO) in phosphate buffer solution (PBS) and used in leishmanicidal assay.

The promastigotes of Leishmania amazonensis PH8 strain (IFLA/BR/67/PH8) were harvested on the $5^{\text {th }}$ day of growth (stationary phase) for the in vitro assays. The parasites $\left(5 \times 10^{5}\right.$ per well) were incubated at $24{ }^{\circ} \mathrm{C}$ for $96 \mathrm{~h}$ in duplicate on RPMI culture medium with or without $1600,800,400,200,100,50,25.5,6.25 \mu \mathrm{g} / \mathrm{mL}$ of TMPP. Viability of parasites was determined daily by erythrosin B $(0.04 \%$ in PBS) dye exclusion.

All experiments were performed in duplicate, and the results expressed as logarithmic number of cells per milliliter and as a percentage of growth inhibition. Two positive controls were prepared with $1600 \mu \mathrm{g} / \mathrm{mL}$ Pentamidine $^{\circledR}$ (pentamidine isethionate) and $1600 \mu \mathrm{g} /$ $\mathrm{mL}$ Glucantime $^{\circledR}$ (meglumine antimoniate). Inhibitory Concentrations (IC) were calculated by Probit Analysis (Minitab 14).<smiles>COc1cc(CCC(=O)O)cc(OC)c1OC</smiles>

1

\section{RESULTS AND DISCUSSION}

The 3-(3,4,5-trimethoxyphenyl) propanoic acid (1) (TMPP) interfered with the promastigote replication. On the third day of incubation, a significant decrease in the parasite growth induced by TMPP (1600 and $800 \mu \mathrm{g} / \mathrm{mL}$ ) and the presence of some dead parasites was observed. After $96 \mathrm{~h}$ of incubation, the calculated inhibitory concentrations were $145 \mu \mathrm{g} / \mathrm{mL}$ and $703 \mu \mathrm{g} /$ $\mathrm{mL}$ for IC50 and IC90, respectively. The Pentamidine ${ }^{\circledR}$ eliminated $100 \%$ of promastigotes after $24 \mathrm{~h}$ of incubation at $1600 \mu \mathrm{g} / \mathrm{mL}$. However, Glucantime ${ }^{\circledR}$ at $1600 \mu \mathrm{g} /$ $\mathrm{mL}$ inhibited only approximately $22.5 \%$, similar to the growth inhibition by $200 \mu \mathrm{g} / \mathrm{mL}$ of TMPP (Figure 1). It is believed that antimony, like glucantime, may be a prodrug and is converted to trivalent antimony after administration, interfering in the process of $\beta$-oxidation of fatty acids and of glycolysis in the parasite (Croft \& Coombs, 2003). For over ninety years the drug based on antimony is the first 
choice in the treatment of leishmaniasis. The demand for new drugs for leishmaniasis cure, which affect the life cycle of the parasite, is necessary, to replace the treatment of first choice. The present results suggest that the TMPP was more efficient than Glucantime ${ }^{\circledR}$ and may be a new bioactive leishmanicidal compound.

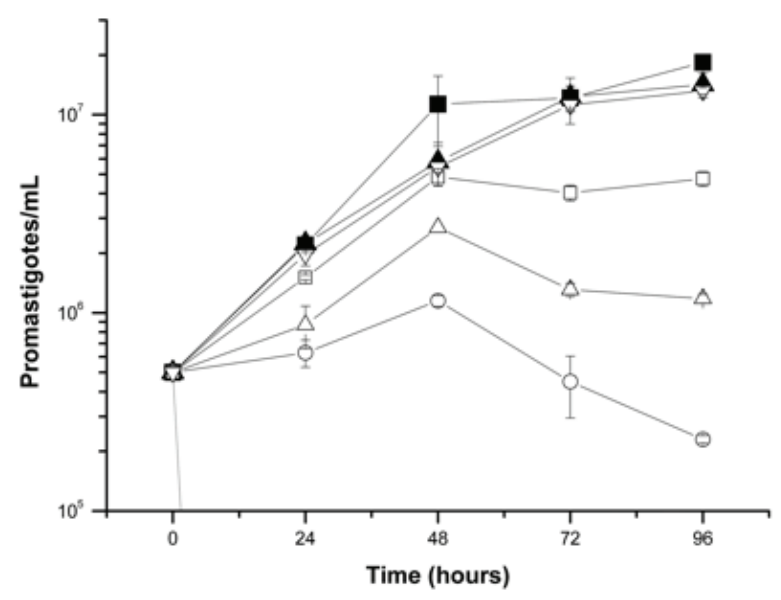

Figure 2. Growth curve of L. amazonensis promastigotes forms in the following conditions: control (匹); $1600 \mu \mathrm{g} / \mathrm{mL}$ of Glucantime ${ }^{\circledR}(\boldsymbol{\Delta}) ; 1600 \mu \mathrm{g} / \mathrm{mL}$ of Pentamidime ${ }^{\circledR}(---)$; and TMPP at $200 \mu \mathrm{g} / \mathrm{mL}(\boldsymbol{\nabla}), 400 \mu \mathrm{g} / \mathrm{mL}(\square), 800 \mu \mathrm{g} / \mathrm{mL}$ ( $\Delta$ ) and $1600 \mu \mathrm{g} / \mathrm{mL}(\circ)$. The experiment started with $5 \times 10^{5}$ parasites in all samples.

The Piperaceae family is under investigation by many laboratories and presents important perspectives for drugs development (Calderon et al., 2009). This is the first report of leishmanicidal activity of TMPP. Other natural products with leishmanicidal activity were isolated from other Piper species, such as methyl 3,4dihydroxy-5-(3'-methyl-2'-butenyl)benzoate (Flores et al., 2008), several prenylated benzoic acids (Flores et al., 2009), kavapyrone and some chalcones (Flores et al., 2007).

Although additional tests involving this natural product, such as pharmacological and toxicological studies, are required for the elucidation of the TMPP mechanism of action in the promastigote replication, these results might be useful in the identification of natural products' candidates for the development of new antileishmanial drugs.

\section{CONCLUSION}

The 3-(3,4,5-trimethoxyphenyl) propanoic acid (1) purified from Piper tuberculatum Jacq., Piperaceae, fruits inhibited the growth of L. amazonensis promastigotes with an IC50 value of $145 \mu \mathrm{g} / \mathrm{mL}$.

\section{ACKNOWLEDGEMENTS}

The authors are grateful Dr. J. Gomes from Instituto Nacional de Pesquisa da Amazônia (INPA) for identification of plant material, and CT-Amazonia/CNPq, FINEP and Pronex/CNPq/Seplad/RO for the financial support.

\section{REFERENCES}

Bezerra DP, Castro FO, Alves APNN, Pessoa C, Moraes MO, Silveira ER, Lima MAS, Elmiro FJM, Costa-Lotufo LV 2006. In vivo growth-inhibition of Sarcoma 180 by piplartine and piperine, two alkaloid amides from Piper. Braz J Med Biol Res 39: 801-807.

Calderon LA, Silva-Jardim I, Zuliani JP, Silva AA, Ciancaglini P, Silva LHP, Stábeli RG 2009. Amazonian biodiversity: a view of drug development for leishmaniasis and malaria. J Braz Chem 20: 1011-1023.

Chaves MCO, Junior AGF, Santos BVO 2003. Amides from Piper tuberculatum fruits. Fitoterapia 74: 181-183.

Croft SL, Coombs GH 2003. Leishmaniasis-current chemotherapy and recent advances in the search for novel drugs. Trends Parasitol 19: 502-508.

Duarte CDM, Verli H, Araujo-Junior JXD, Medeiros IAD, Barreiro EJ, Fraga CAM 2004. New optimized piperamide analogues with potent in vivo hypotensive properties. Eur J Pharm Sci 23: 363-369.

Facundo VA, Pollli AR, Rodrigues RV, Militão JSLT, Stabelli RG, Cardoso CT 2008. Fixed and volatile chemical constituents from stems and fruits of Piper tuberculatum Jacq. and from roots of P. hispidum. Acta Amaz 38: 743748 .

Flores N, Cabrera G, Jiménez IA, Piñero J, Giménez A, Bourdy G, Cortés-Selva F, Bazzocchi IL 2007. Leishmanicidal constituents from the leaves of Piper rusbyi. Planta Med 73: 206-211.

Flores N, Jiménez IA, Giménez A, Ruiz G, Gutiérrez D, Bourdy G, Bazzocchi IL 2008. Benzoic acid derivatives from Piper species and their antiparasitic activity. J Nat Prod 71: 1538-1543.

Flores N, Jiménez IA, Giménez A, Ruiz G, Gutiérrez D, Bourdy G, Bazzocchi IL 2009. Antiparasitic activity of prenylated benzoic acid derivatives from Piper species. Phytochemistry 70: 621-627.

Fontenele JB, Leal LK, Silveira ER, Felix FH, Bezerra CF, Viana GS 2009. Antiplatelet effects of piplartine, an alkamide isolated from Piper tuberculatum: possible involvement of cyclooxygenase blockade and antioxidant activity. $J$ Pharm Pharmacol 61: 511-515.

Jaramillo MA, Manos PS 2001. Phylogeny and patterns of floral diversity in the genus Piper (Piperaceae). Am J Bot 88: 706-716.

Kato MJ, Furlan M 2007. Chemistry and evolution of the Piperaceae. Pure Appl Chem 79: 529-538.

Lago JHG, Ramos CS, Casanova DCC, Morandim AA, 
Bergamo DCB, Cavalheiro AJ, Bolzani VS, Furlan M, Guimarães EF, Young MCM, Kato MJ 2004. Benzoic acid derivatives from Piper species and their fungitoxic activity against Cladosporium cladosporioides and $C$. sphaerospermum. J Nat Prod 67: 1783-1788.

Paula-Junior W, Rocha FH, Donatti L, Fadel-Picheth CMT, Weffort-Santos AM 2006. Leishmanicidal, antibacterial, and antioxidant activities of Caryocar brasiliense Cambess leaves hydroethanolic extract. Rev Bras Farmacogn 16: 625-630.

Pohlit AM, Quignard ELJ, Nunomura SM, Tadei WP, Hidalgo AF, Pinto ACS, Santos EVM, Moraes SKR, Saraiva RCG, Ming LC, Alecrim AM, Ferraz AB, Pedroso ACS, Diniz EV, Finney EK, Gomes EO, Dias HB, Souza KS, Oliveira LCP, Don LC, Queiroz MMA, Henrique MC, Santos M, Lacerda Jr OS, Pinto PS, Silva SG, Graça YR 2004. Screening of plants found in the State of Amazonas, Brazil for larvicidal activity against Aedes aegypti larvae. Acta Amaz 34: 97-105.

Reithinger R, Dujardin JC, Louzir H, Pirmez C, Alexander B, Brooker S 2007. Cutaneous leishmaniasis. Lancet Infect Dis 7: 581-96.

Rocha LGR, Aragão CFS, Loiola MIB, Bezerril RA, Paiva NRF, Holanda CMCX, Brito MEF 2009. Evaluation of the leishmanicide action of ethanol extracts of Crotalaria retusa L. (Fabaceae). Rev Bras Farmacogn 19: 51-56.

Rocha SFR, Ming LC 1999. Piper hispidinervum: A sustainable source of safrole. In: Janick J (org.). Perspectives on new crops and new uses. Alexandria: ASHS Press, p.479-481.

Santos DO, Coutinho CE, Madeira MF, Bottino CG, Vieira RT, Nascimento SB, Bernardino A, Bourguignon SC, CorteReal S, Pinho RT, Rodrigues CR, Castro HC 2008. Leishmaniasis treatment-a challenge that remains: a review. Parasitol Res 103: 1-10.

Wadt LHO, Ehringhaus C, Kageyama PY 2004. Genetic diversity of "Pimenta Longa" genotypes (Piper spp., Piperaceae) of the Embrapa Acre germplasm collection. Genet Mol Biol 27: 74-82.

\footnotetext{
\# Taken in part from a memorial submitted by MGPRS to the Federal University of Rondonia in partial fulfillment of the requirement for the Master degree in Experimental Biology.
} 